Syntax Literate : Jurnal Ilmiah Indonesia p-ISSN: 2541-0849

e-ISSN : 2548-1398

Vol. 6, No. 2, Februari 2021

\title{
EFEKTIVITAS PELAYANAN PENGADUAN DI PERUSAHAAN DAERAH AIR MINUM (PDAM) GIRI TIRTA KABUPATEN GRESIK
}

\section{Lulu Syafirah dan Ertien Rining Nawangsari}

Universitas Pembangunan Nasional (UPN) Veteran, Jawa Timur, Indonesia

Email: lulusyafira00@gmail.com dan ertien.riningnawangsari@yahoo.com

\begin{abstract}
The purpose of this study was to determine the effectiveness of services at PDAM Giri Tirta, Gresik Regency. This research was conducted at PDAM Giri Tirta, Gresik Regency. The availability of water is very necessary for the daily needs of the community and water availability is very much needed during the current pandemic. During a pandemic like now there is a recommendation from the government based on health protocols to wash hands frequently as one of the breakers in the chain of spreading the virus, so as a public service, PDAM Giri Tirta, Gresik Regency is demanded to continue to provide optimal service to the community. This study used descriptive qualitative method. Researchers will look for data related to research, while the data collection techniques in this study are by 3 ways, namely, interviews, observation, and documentation. The results of the study were conducted through interviews with 2 employees of PDAM Giri Tirta, Gresik Regency and several customers who made complaints. Discussion of research with the results of interviews and linked to conceptual findings related to research.
\end{abstract}

Keywords: effectiveness, complaints service, pandemic

\begin{abstract}
Abstrak
Tujuan dari penelitian ini untuk mengetahui efektivitas pelayanan di PDAM Giri Tirta Kabupaten Gresik. Penelitian ini dilakukan di PDAM Giri Tirta Kabupaten Gresik. Ketersediaan air sangat diperlukan untuk kebutuhan sehari-hari masyarakat dan air sangat dibutuhkan ketersediaannya pada masa pandemi saat ini. Di masa pandemi seperti sekarang terdapat anjuran dari pemerintah berdasarkan protokol kesehatan untuk sering mencuci tangan sebagai salah satu pemutus mata rantai penyebaran virus, maka sebagai pelayanan publik PDAM Giri Tirta Kabupaten Gresik di tuntut untuk terus memberikan pelayanan yang optimal kepada masyarakat. Penelitian ini menggunakan metode deskriptif kualitatif. Peneliti akan mencari data yang berhubungan dengan penelitian, adapun teknik pengumpulan data dalam penelitian ini yaitu dengan 3 cara yaitu, wawancara, observasi, dan dokumentasi. Hasil penelitian dilakukan melalui wawancara dengan 2 pegawai PDAM Giri Tirta Kabupaten Gresik dan beberapa pelanggan yang melakukan pengaduan. Pembahasan penelitian dengan hasil wawancara dan dihubungkan dengan temuan-temuan konsep yang berkaitan dengan penelitian.
\end{abstract}

Kata kunci: efektivitas, pelayanan pengaduan, pandemi 
Coresponden Author

Email: lulusyafira00@gmail.com

Artikel dengan akses terbuka dibawah lisensi

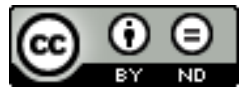

\section{Pendahuluan}

Air merupakan salah satu bentuk sumber daya nasional yang menjadi kebutuhan pokok bagi seluruh anggota masyarakat, salah satunya adalah kebutuhan akan air minum. Hal tersebut sesuai dengan ketentuan di dalam Undang-Undang Republik Indonesia Nomor 7 Tahun 2004 Tentang Sumber Daya Air yang menjelaskan bahwa pengembangan sistem penyediaan air minum menjadi tanggung jawab Pemerintah dan Pemerintah Daerah dalam rangka mewujudkan kesejahteraan masyarakat dengan melakukan jaminan standar kebutuhan pokok air minum bagi masyarakat yang memenuhi syarat kualitas, kuantitas, dan kontinuitas.

Sehingga guna menunjang ketersedian air sebagai kebutuhan masyarakat, maka harus ada pengelolaan sistem terkait dengan ketersediaan air karena air menjadi barang publik yang dikonsumsi oleh masyarakat untuk dikelola oleh negara dan dijamin pemenuhannya oleh pemerintah. Dan dengan demikian pengelolaan ketersediaan air mencukupi sebagai salah satu cara untuk melakukan pendistribusian air dengan optimal ke seluruh daerah. Namun pada kenyataannya, debit air yang tersedia terbatas sehingga masyarakat kesulitan mendapatkan air bersih, hal ini menyebabkan kebutuhan air bersih tidak sepenuhnya terpenuhi. Hal tersebut sejalan berdasarkan pada Undang-Undang Republik Indonesia Nomor 7 Tahun 2004 Tentang Sumber Daya Air pasal 5 yang menyatakan bahwa negara menjamin hak setiap warga untuk mendapatkan air bagi kebutuhan pokok sehari-hari guna memenuhi kehidupannya yang bersih, sehat, dan produktif. Air memiliki peranan penting untuk mendukung kemakmuran dan kesejahteraan masyarakat. Seiring dengan bertambahnya penduduk maka kebutuhan air akan semakin meningkat. Oleh karena itu pemerintah mengelola sebuah perusahaan yaitu Perusahaan Daerah Air Minum yang biasanya lebih dikenal sebagai PDAM

Berdasarkan penjelasan diatas badan atau organisasi yang mengelola dan mengatur pendistribusian air yaitu PDAM, yang mana menurut Undang-Undang RI No.5, 1962 PDAM merupakan suatu kesatuan usaha milik pemerintah daerah yang memberikan jasa pelayanan dan penyelenggaraan secara umum yang terus berupaya menciptakan kinerja pegawai yang berkualitas dan bertanggung jawab kepada masyarakat dalam memberikan pelayanan yang baik serta mengimplementasikan $3 \mathrm{~S}$ (Senyum, Salam, Sapa) baik kepada sesama pegawai maupun kepada pelanggan. PDAM yang memiliki tujuan untuk meningkatkan pelayanan yang baik guna memenuhi prinsip kualitas, kuantitas, dan kontinuitas kepada masyarakat. Sehingga keberadaan PDAM dibutuhkan oleh masyarakat untuk mencukupi kebutuhan air bersih yang layak untuk di konsumsi. Dalam hal ini, pengelolaan air menjadi poin yang sangat penting, karena dengan adanya pengelolaan, maka air bersih yang tersedia dapat dikelola dan diolah dengan sebaik mungkin yang kemudian didistribusikan secara merata kepada 
seluruh masyarakat. Oleh karena itu, guna menjamin pendistribusian air yang merata kepada masyarakat maka perlu adanya peningkatan kinerja dari para pegawai PDAM guna menunjang terciptanya pelayanan yang berkualitas dengan senantiasa memperhatikan efektivitas serta efisiensi dari bentuk pelayanan yang diberikan kepada masyarakat. Menurut (Febliany, Imelda Fitriyah, Nur Paselle, Enos, 2017) efektivitas merupakan konsep untuk mengukur produktivitas, menunjukkan sampai seberapa jauh tercapainya suatu tujuan yang terlebih dahulu ditentukan. Sedangkan menurut (Waruwu \& Masitho, 2016) efektivitas merupakan salah satu pencapaian yang ingin diraih oleh instansi pemerintah agar dapat memuaskan masyarakat. Berdasarkan penjelasan diatas maka hampir seluruh PDAM yang ada di Indonesia selalu berupaya memberikan pelayanan yang baik dan optimal kepada masyarakat, tidak terkecuali PDAM Giri Tirta yang berada di Kabupaten Gresik. PDAM Giri Tirta Kabupaten Gresik adalah salah satu Perusahaan Daerah Air Minum yang diberi tugas mengelola air bersih untuk memenuhi kebutuhan masyarakat Kabupaten Gresik yang tersebar baik di pedesaan maupun di perkotaan.

Sehingga, untuk mencapai tujuan PDAM dalam mewujudkan air bersih, diperlukannya pelayanan publik yang baik kepada masyarakat baik terkait dengan pelayanan pengaduan secara administrasi maupun teknis. Untuk segala penyelenggaraan pelayanan pengaduan dilaksanakan oleh seluruh kantor, baik kantor cabang ataupun unit pelayanan. Pelayanan tersebut diperlukan untuk membantu masyarakat agar segera mendapatkan penanganan atas berbagai permasalahannya sehingga permasalahan tersebut dapat terselesaikan dengan cepat dan tepat. Menurut (Ruru, 2015) menyatakan bahwa pelayanan adalah suatu kegiatan atau urutan kegiatan yang terjadi dalam interaksi langsung antar seseorang dengan orang lain atau mesin secara fisik, dan menyediakan kepuasan pelanggan.

Sedangkan Menurut (Ardianor \& Suriyani, 2017) menyatakan bahwa pelayanan adalah suatu kegiatan dikantor atau didalam suatu organisasi yang dilaksanakan setiap hari kerja oleh para pegawai atau petugas yang ditunjuk untuk melayani keperluan masyarakat dalam urusan adminstrasi umum dengan ukuran cepat, tepat waktu dan benar. Hal tersebut perlu dilakukan didalam menyelesaikan suatu permasalahan yang dialami masyarakat sehingga keberadaan pelayanan didalam suatu instansi atau organisasi untuk menyelesaikan masalah tersebut sangat penting karena pemberian pelayanan publik merupakan tugas utama bagi aparatur negara yang pada dasarnya merupakan pelayan bagi masyarakat. Dalam Undang-Undang Nomor 25 Tahun 2009 tentang Pelayanan Publik, menyatakan bahwa pelayanan publik adalah serangkaian kegiatan dalam rangka pemenuhan kebutuhan pelayanan sesuai dengan peraturan perundang-undangan bagi setiap warga negara dan penduduk atas barang, jasa, dan atau pelayanan administratif yang disediakan oleh penyelenggara pelayanan publik. Dalam pandangan lain Menurut Agung Kurniawan dalam Pasolong (2013:132) dikutip oleh (Indrawati, Suntoro, \& Nurmalisa, 2017) menyatakan bahwa pelayanan publik adalah pemberian pelayanan (melayani) keperluan orang lain atau masyarakat yang mempunyai kepentingan pada organisasi itu sesuai dengan aturan pokok dan tata cara 
yang telah ditetapkan. Sedangkan menurut (Sari, 2019) menyatakan bahwa pelayanan publik adalah segala kegiatan yang dilaksanakan oleh penyelenggara pelayanan publik sebagai upaya pemenuhan kebutuhan penerima pelayanan, dalam pelaksanaan ketentuan peraturan perundangundangan. Dan menurut (J Jumarianto, 2017) menyatakan bahwa pelayanan publik dapat diartikan sebagai pemberian layanan (melayani) keperluan orang atau masyarakat yang mempunyai kepentingan pada organisasi itu sesuai dengan aturan pokok dan tata cara yang telah ditetapkan.

Dalam Kemenpan No. 14 Tahun 2017 tentang Pedoman Penyusunan Survei Kepuasan Masyarakat Unit Penyelenggara Pelayanan Publik, menyatakan bahwa unit pelayanan publik adalah unit kerja atau kantor pelayanan pada instansi pemerintah, yang secara langsung maupun tidak langsung memberikan pelayanan kepada penerima pelayanan. Sehingga pelayanan publik menjadi tolak ukur atas kinerja dari sebuah instansi, karena pelayanan merupakan suatu bentuk yang dilakukan oleh instansi atau organisasi untuk melakukan pengabdiannya kepada masyarakat. Sehingga urgensi dari pelayanan publik menentukan optimal atau tidaknya pelayanan yang diberikan kepada masaarakat dan manfaat atau dampak apa saja yang diterima oleh masyarakat sebagai penerima pelayanan. Oleh karena itu, suatu instansi atau organisasi harus melakukan langkah yang efektif dalam memberikan pelayanan kepada pelanggan atau masyarakat. Sebab, pelayanan akan selalu ada pada organisasi tidak terkecuali pada PDAM yang merupakan suatu perusahaan daerah yang memberikan pelayanan terkait dengan penyediaan dan pendistribuasian air. Berdasarkan penjelasan tersebut ada beberapa faktor yang mempengaruhi PDAM untuk senantiasa melakukan pelayanan yang prima kepada masyarakat yaitu pertumbuhan penduduk, perkembangan pembangunan, dan meningkatnya standar kehidupan menyebabkan kebutuhan masyarakat akan air yang semakin meningkat.

Oleh karena itu, dengan terjadinya perkembangan masyarakat, menuntut birokrasi publik untuk lebih responsif dalam memberikan pelayanan. Sehingga pemerintah dituntut untuk terus memberikan pelayanan yang baik kepada masyarakat, karena pelayanan publik dilaksanakan dengan tujuan memberikan kepuasan kepada masyarakat. Pelayanan yang diberikan oleh suatu organisasi dilihat dari banyaknya pelanggan atau masyarakat yang membutuhkan pelayanan, sebab kuantitas pelanggan yang akan menentukan jalannya kebijakan atau peraturan yang akan dijalankan oleh suatu organisasi dalam memeberikan pelayanan yang prima kepada masayarakat atau pelanggan selaku penerima pelayanan. Berdasarkan penjelasan tersebut berikut jumlah pelanggan yang ada di PDAM Giri Tirta Kabupaten Gresik yakni: 
Tabel 1

Jumlah Pelanggan Perusahaan Daerah Air Minum Giri Tirta Kabupaten Gresik

\begin{tabular}{rlrrrrr}
\hline \multirow{2}{*}{ NO } & \multirow{2}{*}{ Uraian } & \multicolumn{5}{c}{ Tahun } \\
\cline { 3 - 7 } & & $\mathbf{2 0 1 5}$ & $\mathbf{2 0 1 6}$ & $\mathbf{2 0 1 7}$ & $\mathbf{2 0 1 8}$ & \multicolumn{2}{c}{$\mathbf{2 0 1 9}$} \\
\hline 1 & Sosial Umum & 63 & 67 & 79 & 91 & 106 \\
\hline 2 & Sosial Khusus & 938 & 983 & 1038 & 1075 & 1124 \\
\hline 3 & Rumah Tangga & 78.226 & 82.608 & 85.889 & 89.720 & 93.614 \\
\hline 4 & Instansi Pemerintah & 147 & 161 & 168 & 176 & 181 \\
\hline 5 & Niaga Kecil & 3.140 & 3.318 & 3.581 & 3.585 & 3.652 \\
\hline 6 & Niaga Besar & 345 & 355 & 457 & 484 & 558 \\
\hline 7 & Industri Kecil & 89 & 95 & 84 & 85 & 83 \\
\hline 8 & Industri Besar & 203 & 213 & 218 & 215 & 226 \\
\hline 9 & Khusus & 1 & 1 & 2 & 1 & 1 \\
\hline & Jumlah & 83.153 & 87.801 & 91.516 & 95.432 & 99.545 \\
\hline
\end{tabular}

Sumber : PDAM Giri Tirta Kabupaten Gresik 2020

Berdasarkan data diatas mulai tahun 2015-2019 terjadi peningkatan permintaan akan penyediaan air bersih dari masyarakat. Pada tahun 2015 PDAM Giri Tirta Kabupaten Gresik memiliki jumlah pelanggan sebanyak 83.153 pelanggan. Pada tahun 2016 tercatat 87.801 pelanggan. Pada tahun 2017 tercatat 91.516 pelanggan. Pada tahun 2018 tercatat 95.432 pelanggan. Dan pada tahun 2019 tercatat 99.545 pelanggan. Seiring dengan pesatnya peningkatan permintaan pemenuhan air di Kabupaten Gresik, maka sangat diperlukan adanya sistem pengelolaan dan pendistribuasian air yang maksimal agar kebutuhan air masyarakat dapat terpenuhi. Karena saat ini PDAM Giri Tirta Kabupaten Gresik merupakan satu-satunya perusahaan penyedia air untuk masyarakat di Kabupaten Gresik dan sekitarnya.

Sehingga berdasarkan penjelasan diatas PDAM Giri Tirta Kabupaten Gresik harus memaksimalkan sumber daya yang ada dalam mewujudkan pelayanan yang optimal sebagaimana yang tertuang pada Pearturan Daerah Kabupaten Gresik Nomor 14 Tahun 2013 tentang Perusahaan Daerah Air Minum (PDAM) Giri Tirta Kabupaten Gresik menyatakan bahwa untuk lebih meningkatkan kinerja pelayanan kepada masyarakat dan fungsi PDAM Kabupaten Gresik sebagai Perusahaan Daerah yang mandiri berdasarkan prinsip-prinsip ekonomi yang sehat, maka perlu dilakukan penataan organisasi dan kepegawaian PDAM Kabupaten Gresik. Akan tetapi pada realitanya masih banyak berbagai permasalahan yang terjadi terkait dengan banyaknya hambatan di dalam melakukan pengelolaan dan pendistribusian air bersih. Hal tersebut juga terjadi pada PDAM Giri Tirta di Kabupaten Gresik yang mengalami berbagai bentuk permasalahan dalam melakukan pengelolaan dan pendistribusian air bersih. Akibatnya dari berbagai permasalahan yang terjadi berdampak pada banyaknya keluhan atau pengaduan pelanggan PDAM Giri Tirta di Kabupaten Gresik terkait dengan pelayanan yang diberikan. Pengaduan pelanggan kepada PDAM Giri Tirta Kabupaten Gresik terkait dengan fasilitas air yang banyak terjadi, seperti air keruh, mati air, 
kebocoran pipa, sampai alat pencatat meter rusak. Dari berbagai permasalahan yang terjadi di PDAM Giri Tirta di Kabupaten Gresik terkait dengan keluhan masyarakat atau pelanggan mengenai ketersediaan air yang minim dan terus-menerus terjadi kemacetan air membuat permasalahan tersebut tak kunjung usai. Berikut data terkait dengan keluhan pelanggan di Perusahaan Daerah Air Minum (PDAM) Giri Tirta Kabupaten Gresik antara lain :

\section{Tabel 2}

Jumlah Pengaduan Pelanggan Perusahaan Daerah Air Minum Giri Tirta Kabupaten Gresik Tahun 2019

\begin{tabular}{llccccc}
\hline No. & \multicolumn{1}{c}{ Uraian } & Pekerjaan & Selesai & $\mathbf{\%}$ & $\begin{array}{c}\text { Proses } \\
\text { Belum } \\
\text { Selesai }\end{array}$ & \% \\
\hline $\mathbf{1 .}$ & JANUARI & 1.000 & 889 & $88,9 \%$ & 111 & $11,1 \%$ \\
\hline $\mathbf{2 .}$ & FEBRUARI & 770 & 647 & $84,0 \%$ & 123 & $16,0 \%$ \\
\hline $\mathbf{3 .}$ & MARET & 812 & 789 & $97,2 \%$ & 23 & $2,8 \%$ \\
\hline $\mathbf{4 .}$ & APRIL & 622 & 611 & $98,2 \%$ & 11 & $1,8 \%$ \\
\hline $\mathbf{5 .}$ & MEI & 927 & 901 & $97,2 \%$ & 26 & $2,8 \%$ \\
\hline $\mathbf{6 .}$ & JUNI & 885 & 848 & $95,8 \%$ & 37 & $4,2 \%$ \\
\hline $\mathbf{7 .}$ & JULI & 1.795 & 1.737 & $96,8 \%$ & 58 & $3,2 \%$ \\
\hline $\mathbf{8 .}$ & AGUSTUS & 951 & 923 & $97,1 \%$ & 28 & $2,9 \%$ \\
\hline $\mathbf{9 .}$ & SEPTEMBER & 1.568 & 1.524 & $97,2 \%$ & 44 & $2,8 \%$ \\
\hline $\mathbf{1 0 .}$ & OKTOBER & 2.539 & 2.522 & $99,3 \%$ & 17 & $0,7 \%$ \\
\hline $\mathbf{1 1 .}$ & NOVEMBER & 1.788 & 1.775 & $99,3 \%$ & 13 & $0,7 \%$ \\
\hline $\mathbf{1 2 .}$ & DESEMBER & 1.125 & 1.115 & $99,1 \%$ & 10 & $0,9 \%$ \\
\hline & Total Jumlah & $\mathbf{1 4 . 7 8 2}$ & $\mathbf{1 4 . 2 8 1}$ & $\mathbf{9 5 , 8 \%}$ & $\mathbf{5 0 1}$ & $\mathbf{4 , 2 \%}$ \\
\hline & & & & & & \\
\hline
\end{tabular}

Sumber : PDAM Giri Tirta Kabupaten Gresik 2020

Berdasarkan data table 2 jumlah pengaduan pelanggan di PDAM Giri Tirta Kabupaten Gresik pada tahun 2019 mulai dari bulan Januari sampai Desember berjumlah 14.782 pengaduan pelanggaan dengan presentase penyelesaian kasus pengaduan sebesar $95,8 \%$ atau sekitar 14.281 kasus yang terselesaikan. Sedangakan berdasarkan data tersebut presentase total kasus yang belum terselesaikan sebesar 4,2\% atau sekitar 501 kasus. Dari hasil penjelasan tersebut walaupun total kasus yang belum terselesaikan dengan kasus yang sudah terselesaikan perbandingannya jauh, akan tetapi hal tersebut merupakan dasar yang dapat dijadikan PDAM Giri Tirta Kabupaten Gresik dalam memberikan pelayanan yang lebih optimal. Sebab dari 501 kasus yang belum terselesaikan pada tahun 2019 belum ada tindak penyelesaian atau bahkan langkah persuasif yang dilakukan sehingga kasus-kasus tersebut dibiarkan dan membuat masyarakat merasa bahwa dampak yang dirasakan selalu terjadi dan terus berulang terkait dengan pasokan air yang dilakukan PDAM Giri Tirta Kabupaten Gresik pada masyarakat atau pelanggan. Instansi atau organisasi terutama PDAM Giri Tirta Kabupaten Gresik lebih cepat dalam menangani permasalahan yang ada agar permasalahan tersebut tidak membuat masayarakat kecewa akan pelayanan yang diberikan seperti seringnya mati air, bahkan warna air sering keruh. Jumlah total 
pengaduan di PDAM Giri Tirta Kabupaten Gresik dibedakan menjadi dua bagian pengaduan pelanggan yaitu pengaduan pelanggan masalah teknis dan pengaduan pelanggan masalah administrasi. Jumlah pengaduan pelanggan masalah teknis dan Jumlah pengaduan pelanggan masalah adminitrasi di PDAM Giri Tirta Kabupaten Gresik sebagai berikut:

Tabel 3

Jumlah Pengaduan Pelanggan Masalah Teknis Perusahaan Daerah Air Minum Giri Tirta Kabupaten Gresik Tahun 2019

\begin{tabular}{llccccc}
\hline No. & \multicolumn{1}{c}{ Uraian } & Pekerjaan & Selesai & \% & $\begin{array}{c}\text { Proses } \\
\text { Belum } \\
\text { Selesai }\end{array}$ & \\
\hline 1. & SR (Instalasi) & 4.410 & 4.300 & $97,5 \%$ & 110 & $2,5 \%$ \\
\hline 2. & Tersier & 1.931 & 1.759 & $91 \%$ & 172 & $9 \%$ \\
\hline 3. & Transmisi & 329 & 300 & $91,2 \%$ & 29 & $8,8 \%$ \\
\hline 4. & $\begin{array}{l}\text { Pindah Lokasi } \\
\text { Meter }\end{array}$ & 86 & 85 & $98,8 \%$ & 1 & $1,2 \%$ \\
\hline 5. & $\begin{array}{l}\text { Cek Akurasi/ Tera } \\
\text { Meter }\end{array}$ & 800 & 798 & $99,8 \%$ & 2 & $0,2 \%$ \\
\hline 6. & Ganti Meter & 3.860 & 3.677 & $95,3 \%$ & 183 & $4,7 \%$ \\
\hline & Total Jumlah & $\mathbf{1 1 . 4 1 6}$ & $\mathbf{1 0 . 9 1 9}$ & & $\mathbf{4 9 7}$ & \\
\hline
\end{tabular}

Sumber : PDAM Giri Tirta Kabupaten Gresik 2020

Tabel 4

Jumlah Pengaduan Pelanggan Masalah Administrasi Perusahaan Daerah Air Minum Giri Tirta Kabupaten Gresik Tahun 2019

\begin{tabular}{llccccc}
\hline No. & \multicolumn{1}{c}{ Uraian } & Pekerjaan & Selesai & $\%$ & $\begin{array}{c}\text { Proses } \\
\text { Belum } \\
\text { Selesai }\end{array}$ & $\%$ \\
\hline 1. & Revisi Alamat & 124 & 124 & $100 \%$ & 0 & $0 \%$ \\
\hline 2. & Balik Nama & 265 & 260 & $98 \%$ & 5 & $2 \%$ \\
\hline 3. & Revisi Diameter & 1 & 1 & $100 \%$ & 0 & $0 \%$ \\
\hline 4. & Revisi DRD & 2 & 2 & $100 \%$ & 0 & $100 \%$ \\
\hline 5. & Revisi Zona & 0 & 0 & $100 \%$ & 0 & $100 \%$ \\
\hline 6. & Revisi Tarif & 2.974 & 2.972 & $99 \%$ & 2 & $1 \%$ \\
\hline & Total Jumlah & $\mathbf{3 . 3 6 6}$ & $\mathbf{3 . 3 5 9}$ & & $\mathbf{7}$ & \\
\hline
\end{tabular}

Sumber : PDAM Giri Tirta Kabupaten Gresik 2020

Berdasarkan data tabel 4 jumlah total pengaduan pelanggan di PDAM Giri Tirta Kabupaten Gresik terkait masalah teknis berjumlah 11.416 pelanggan dan pengaduan pelanggan terkait masalah administrasi sebanyak 3.366 pelanggan. Dari permasalahan tersebut dapat terlihat bahwa pelayanan yang ada tidak mencakup penyelesaian masalah secara keseluruhan dengan masih adanya masalah atau kasus yang belum terselesaikan. Oleh karena itu, untuk lebih meningkatkan pelayanan kepada masyarakat dan 
mengurangi masalah atau kasus tersebut maka PDAM Giri Tirta Kabupaten Gresik harus mengupayakan sistem pelayanan yang optimal. Pelayanan yang optimal harus tetap dilakukan walaupun pada saat ini negara Indonesia berada pada masa pandemi yang mengharuskan setiap instansi atau organisasi untuk meminimalkan bentuk pelayanan langsung.

Pada awal masa pandemi PDAM Giri Tirta Kabupaten Gresik sempat menghentikan sementara proses pelayanan pengaduan pelanggan untuk sementara waktu karena demi menjalankan himbauan dari pemerintah. Oleh karena itu, PDAM Giri Tirta Kabupaten Gresik dalam memberikan pelayanan kepada masayarakat terutama di masa pandemi, dengan melakukan akses pelayanan publik yang diarahkan untuk meminimalkan tatap muka atau datang ke kantor maka PDAM Giri Tirta Kabupaten Gresik dengan upaya pencegahan melalui penyelenggaraan layanan diantaranya pembaruan jam layanan, jangka waktu layanan, penambahan syarat layanan serta mekanisme layanan dari pelayanan secara langsung menjadi pelayanan secara online (daring).

Dalam pencegahan covid-19, layanan online (daring) dapat dijadikan salah satu cara atau alternatif dalam meberikan layanan sehingga masalah atau kasus pengaduan masyarakat tidak menambah dan menumpuk walaupun penanganannya dilakukan secara online (daring) namun tidak menghilangkan layanan secara langsung kepada masyarakat. Meskipun ada pengaruh situasi dan kondisi pada masyarakat di masa pandemi PDAM Giri Tirta Kabupaten Gresik mendukung program pemerintah dimasa pandemi dengan tetap melakukan pelayanan pengaduan pelanggan secara online (daring) agar masalah dapat terselesaikan dengan baik.

Akan tetapi seiring berjalannya kebijakan tersebut dengan mengalihkan sistem pelayanan langsung dengan sistem online (daring) tidaklah memecahkan masalah, sebab masayarakat merasa akses online (daring) penanganannya tidak setanggap ketika melakukan pelaporan secara langsung. Sehingga untuk mencegah permasalahan semakin bertambah, maka PDAM Giri Tirta Kabupaten Gresik membuka kembali sistem pelayanan pengaduan secara langsung dengan syarat mematuhi protokol kesehatan sesuai dengan anjuran pemerintah di masa pandemi covid-19 saat ini. Agar pelayanan dapat berjalan dengan maksimal, perlu adanya usaha untuk mewujudkan keberhasilan pelayanan, sehingga peneliti dapat mengetahui dan melihat sejauh mana efektivitas dari pelayanan tersebut, yang diukur dengan membandingkan antara rencana atau target yang telah ditentukan dengan hasil yang telah dicapai. Jika usaha atau hasil yang dilakukan tidak tercapai sesuai dengan rencana, pelayanan tersebut dapat dikatakan tidak efektif. Begitu pula sebaliknya, jika usaha atau hasil yang dilakukan telah tercapai sesuai dengan rencana, maka pelayanan tersebut dapat dikatakan efektif.

Penelitian ini dapat diukur dengan menggunakan teori Sondang P. Siagian (2019:153) menjelaskan bahwa terdapat beberapa ukuran yang dapat digunakan untuk mengukur efisiensi, efektivitas dan produktuvitas dari organisasi dalam memberikan pelayanan, diantaranya ialah : Pertama, Ukuran waktu : yakni berapa lama waktu yang dibutuhkan oleh seseorang dalam mendapatkan pelayanan di dalam suatu instansi atau 
organisasi. Kedua, Ukuran harga: memiliki arti berapa besar biaya yang harus dikeluarkan untuk memperoleh pelayanan di dalam suatu instansi atau organisasi. Ketiga, Ukuran nilai-nilai sosial budaya: memiliki arti sikap atau cara instansi atau organisasi pemberi pelayanan dalam menyampaikan layanan yang ada kepada pelanggan selaku pengguna pelayanan. Keempat, Ukuran ketelitian: yakni teliti atau cermat dalam melakukan pelayanan yang diberikan kepada pelanggan akurat atau tidak. Jadi, efektivitas perlu dilakukan dengan melihat beberapa ukuran tersebut untuk mengukur efektivitas kerja dari suatu organisasi atau instansi dalam memberikan pelayanan kepada masyarakat atau pelanggan.

\section{Metode Penelitian}

Dalam penelitian ini penulis menggunakan pendekatan penelitian deskriptif kualitatif dengan maksud memberikan suatu gambaran yang komprehensif serta mendalam terkait dengan Efektivitas Pelayanan Pengaduan di PDAM Giri Tirta Kabupaten Gresik. Menurut Sugiyono (2019:18) metode penelitian kualitatif adalah metode penelitian yang berlandas pada filsafat post positivisme digunakan untuk meneliti pada kondisi objek yang alamiah (sebagai lawannya adalah eksperimen), dimana peneliti adalah sebagai instrument kunci, teknik pengumpulan data secara triangulasi (gabungan), analisis data bersifat induktif/kualitatif, dan hasil penelitian kualitatif lebih menekankan makna daripada generalisasi. Teori yang digunakan dalam peneliti ini tidak terlepas pada satu lingkup yang sama dengan masalah yang diteliti. Sondang P Siagian (2019:153) menjelaskan bahwa terdapat beberapa ukuran yang dapat digunakan untuk mengukur efisiensi, efektivitas dan produktuvitas dari organisasi dalam memberikan pelayanan, diantaranya ialah :

1. Ukuran waktu: yaitu berapa lama seseorang yang membutuhkan jasa tertentu untuk memperolehnya.

2. Ukuran harga: yaitu berapa besar biaya yang harus dikeluarkan untuk memperoleh jasa yang dibutuhkannya itu.

3. Ukuran nilai-nilai sosial budaya: yaitu cara penghasil jasa menyampaikan produknya kepada klientnya.

4. Ukuran ketelitian : yaitu ketelitian yang menunjukkan apakah jasa yang diberikan akurat atau tidak.

\section{Hasil dan Pembahasan}

\section{A. Hasil Penelitian}

Hasil penelitian yang dilakukan oleh penulis yang berjudul "Efektivitas Pelayanan Pengaduan di Perusahaan Daerah Air Minum (PDAM) Giri Tirta Kabupaten Gresik" Hal ini merupakan suatu penemuan di lokasi penelitian berdasarkan pengamatan penulis. Maka, untuk mendapatkan data data penulis menggunakan metode observasi, wawancara dan pengambilan data dokumentasi baik data arsip maupun foto. 
Berdasarkan wawancara yang dilakukan penulis pada data jawaban yang bertujuan untuk mengetahui dan menganalisis efeltivitas pelayanan pengaduan di Perusahaan Daerah Air Minum (PDAM) Giri Tirta Kabupaten Gresik. Maka, peneliti melakukan penelitian dengan menggunakan teori dari Sondang P. Siagian (2019:153) menjelaskan bahwa terdapat beberapa ukuran yang dapat digunakan untuk mengukur efisiensi, efektivitas dan produktuvitas dari organisasi dalam memberikan pelayanan, diantaranya, yaitu ukuran waktu, ukuran harga, ukuran nilai-nilai dan sosial budaya, dan ukuran ketelitian. Berikut uraian untuk menjawab dari keempat ukuran tersebut:

\section{Ukuran Waktu}

Ukuran waktu merupakan standar waktu yang ditetapkan dalam melayani pelanggan maupun menindaklanjuti permintaan pelanggan. Penyelenggara pelayanan publik bertanggungjawab atas penyelenggaraan pelayanan dan penyelesaian persoalan dalam pelaksanaan pelayanan publik. Penanganan pengaduan yang telah dilakukan oleh pelanggan harus sesuai dengan ukuran waktu yang telah ditetapkan sesuai SOP (Standar Operasional Prosedur) yang ada. Berikut merupakan hasil wawancara dengan Kepala/sub Bagian Pelayanan Kepelangganan PDAM Giri Tirta Kabupaten Gresik, menyatakan bahwa:

“Oke, jam kerja mulai jam 07.00 pagi-15.00 sore. Lalu untuk lama tidaknya pelayanan itu tergantung kebutuhan setiap pelanggan yang melakukan pengaduan ya mbak, jadi antara satu pengaduan ke pengaduan lainnya dalam menyelesaikan setiap pengaduan tentu beda-beda mbak. Tapi pengaduan disini gak sampai lebih dari 15 menit sudah selesai. Gini, disini kan ada pengaduan masalah teknis dan masalah administrasi. Misalnya, kalau pelanggan datang hari ini melakukan pengaduan masalah teknis maka dalam penyelesaiannya $\mathrm{h}+1$ hari sudah selesai kalau memang ganti meter ya cepet tinggal ganti saja segel sudah selesai. Kalau tepat tidaknya waktu dalam memberikan pelayanan ini sudah tepat ya mbak karena sudah sesuai dengan SOP yang ada dan pelayanan disini sudah cukup efektif ya karena itu tadi mbak masih adanya keluhan-keluhan dari pelanggan yang mungkin harus kita perbaiki lagi" (Wawancara 22 Januari 2021).

Pendapat lain diungkapkan oleh pegawai Pelayanan Kepelangganan PDAM Giri Tirta Kabupaten Gresik yang dapat melengkapi penjelasan diatas. Hasil wawancara sebagai berikut:

"Kalau jam nya, jam kerja kita mulai dari jam 07.00-15.00, tetapi untuk pelayanan onlinenya kami buka di 24 jam. 1 orang pelanggan maksimal 15 menit. Rata-rata waktu yang kami berikan kepada pelanggan sudah tepat sesuai dengan SOP. Untuk efektif tidaknya pelayanan yang kami berikan bisa dikatakan sudah cukup efektif ya mbak karena ya itu tadi masih ada tingkat kesulitan administrasi ini kendalanya seperti itu" (Wawancara 25 Januari 2021).

Pendapat lain disampaikan oleh Ahmad Dumairi, yaitu salah satu pelanggan PDAM Giri Tirta Kabupaten Gresik yang melakukan pengaduan di 
Kantor PDAM Giri Tirta Kabupaten Gresik. Hal ini didukung dengan hasil wawancara sebagai berikut:

"Kurang tepat, jam yang diberikan nggak maksimal kok. Udah jam setengah 9 kok pegawai pelayanannya makan di dalam. Saya bilang ke pegawainya mbak barusan ini gini, katanya pelayanannya ontime kok gak ontime. Yaa kalo efektif tentunya belum mbak karena saya kurang puas dengan pelayanannya" (Wawancara 22 Januari 2021).

Pendapat lain disampaikan oleh Ibu Ita, yaitu salah satu pelanggan PDAM Giri Tirta Kabupaten Gresik yang telah melakukan pengaduan di Kantor PDAM Giri Tirta Kabupaten Gresik. Hal ini didukung dengan hasil wawancara sebgai berikut:

"Tadi ketika saya mengadu penanganannya 15 menitan itu barusan selesai mbak dan itu pun tidak dilayani langsung, jadi ya gitu lumayan lama padahal saya cuma tanya mengenai pemasangan baru. Kalo pelayanannya menurut saya kurang efektif ya mbak" (Wawancara 26 Januari 2021).

Pendapat serupa disampaikan oleh Ibu Komalasari, yaitu salah satu pelanggan PDAM Giri Tirta Kabupaten Gresik yang telah melakukan pembayaran pengaduan di Kantor PDAM Giri Tirta Kabupaten Gresik. Hal ini didukung dengan hasil wawancara sebagai berikut:

"Pembayarannya cepet kok mbak tadi, begitu saya datang untuk membayar tagihan air saya langsung dilayani. Gasampek 5 menit sudah selesai. Kalo efektif cukup efektif mbak, karena tadi mbak kasirnya cemberut terus, gabisa senyum" (Wawancara 26 Januari 2021).

Pendapat serupa disampaikan oleh Ibu Dina, yaitu salah satu pelanggan PDAM Giri Tirta Kabupaten Gresik yang telah melakukan pengaduan di Kantor PDAM Giri Tirta Kabupaten Gresik. Hal ini didukung dengan hasil wawancara sebagai berikut:

"Pelayanannya tadi sekitar 15 menitan tapi waktu saya mengadu itu ndak langsung di proses, pertama dikasihkan ke bapak satunya saya ngadu tapi diimbalin lagi ke bapak satunya lagi dan saya ndak tahu bapak itu bagian apa, pokok e diimbal-imbalkan gitu mbak. Akhir e saya ndak puas, saya minta langsung ke atasannya PDAM nya sendiri. Kalau waktu seh udah tepat sesuai dengan jam kerja nya, tapi kalau dengan kaya pengaduan saya yang diimbalimbalin kaya gini kayanya sih ndak. Haduh mbak, ya jelas kurang efektif, masa ada pelayanan publik seenaknya saja melayani pelanggan" (Wawancara 30 Januari 2021).

Berdasarkan observasi dan wawancara diatas, dinyatakan bahwa ukuran waktu dari pelayanan kepelangganan di PDAM Giri Tirta Kabupaten Gresik ini belum sesuai dengan standar waktu dalam melayani pelanggan, yaitu lebih dari 15 menit. Selain itu, penanganan pegawai kepada masyarakat yang melakukan pengaduan masih kurang cepat tanggap, serta pegawai pelayanan kepelangganan 
PDAM Giri Tirta Kabupaten Gresik terbilang kurang maksimal dalam melayani pelanggan yang melakukan pengaduan.

\section{Ukuran Harga}

Indikator dalam dimensi ini adalah pegawai pelayanan kepelangganan PDAM Giri Tirta Kabupaten Gresik memberikan penjelasan bahwa tidak ada pungutan biaya terkait dengan pelayanan pengaduan dan pegawai juga memberikan kepastian harga atau biaya tambahan dalam pelayanan. Kepastian harga atau biaya tambahan dalam pelayanan ini di khususkan untuk pelanggan yang mengalami pipa bocor, sambungan baru, sampai dengan pencatatan meter rusak. Berikut merupakan hasil wawancara dengan Kepala/sub Bagian Pelayanan Kepelangganan PDAM Giri Tirta Kabupaten Gresik, menyatakan bahwa:

"Ndak ada mbak, kalo kita batasannya di meter mbak, kalo di lapangan ya, kalo pengaduan sebelum meter itu tanggung jawab dari PDAM, Kalo pengaduan setelah meter itu tanggung jawab dari pelanggan. Contohnya, bocor sebelum meter kita yang perbaiki tanpa biaya, kalo meternya rusak itu gratis dari kita. Setelah meter tanggung jawab pelanggan. Kalo meter rusak dari pelanggan, meter hilang itu ada biaya sebesar Rp. 250.000" (Wawancara 22 Januari 2021).

Pendapat lain diungkapkan oleh pegawai Pelayanan Kepelangganan PDAM Giri Tirta Kabupaten Gresik yang dapat melengkapi penjelasan diatas. Hasil wawancara sebagai berikut:

"Eee... aturan disini gaada biaya kecuali perbaikan itu setelah meter air menjadi tanggung jawab pelanggan. Selama ini sebelum meter tidak ada tambahan biaya, seperti meter rusak itu tidak ada biayanya kecuali meter dihilangkan atau di rusakkan dengan pelanggannya sendiri dan besaran biayanya Rp. 250.000” (Wawancara 25 Januari 2021).

Pendapat lain disampaikan oleh Ahmad Dumairi, yaitu salah satu pelanggan PDAM Giri Tirta Kabupaten Gresik yang melakukan pengaduan di Kantor PDAM Giri Tirta Kabupaten Gresik. Hal ini didukung dengan hasil wawancara sebagai berikut:

"Hmm...tidak ada, tidak ada biaya pelayanannya mbak gratis. Tapi kalo seperti saya gini ya mbak melakukan pasang baru kurang lebihnya 2 juta mbak, itu sudah keseluruhannya ya mbak harga nya segitu" (Wawancara 22 Januari 2021)

Pendapat serupa disampaikan oleh Ibu Ita, yaitu salah satu pelanggan PDAM Giri Tirta Kabupaten Gresik yang telah melakukan pengaduan di Kantor PDAM Giri Tirta Kabupaten Gresik. Hal ini didukung dengan hasil wawancara sebgai berikut:

"Untuk pelayanannya tadi gratis mbak saya tidak dipungut biaya sama sekali ya mbak. Kalo pemasangan baru tadi saya dijelasin sama bapaknya termasuk harga pasang baru juga itu kisaran harga nya 1.741.000 ini harga 
yang tertera di brosurnya mbak kalo rumah tangga harganya segitu dan saya dikasih brosurnya ini mbak" (Wawancara 26 Januari 2021).

Pendapat serupa disampaikan oleh Ibu Dina, yaitu salah satu pelanggan PDAM Giri Tirta Kabupaten Gresik yang telah melakukan pengaduan di Kantor PDAM Giri Tirta Kabupaten Gresik. Hal ini didukung dengan hasil wawancara sebagai berikut:

"Tidak ada biaya yang tertera kok mbak mengenai pelayanannya. Gratis. $\mathrm{Hmm}$...pernah sih mbak pasang baru cuma saya gak begitu inget habisnya berapa waktu itu, kira-kira habis sekitar 1.500 .000 an mbak. Pokoknya saya kasih 2 juta itu uang saya masih kembali berapa gitu, lupa saya mbak wong ya udah lama kok itu" (Wawancara 30 Januari 2021).

Berdasarkan observasi dan wawancara diatas, pegawai pelayanan pengaduan di PDAM Giri Tirta Kabupaten Gresik tidak melakukan pemungutan biaya terkait dengan pelayanannya. Namun apabila sebelum meter terdapat kerusakan meter hal itu sudah menjadi tanggungjawab PDAM. Akan tetapi apabila setelah meter terdapat kerusakan meter atau hilangnya meter yang disebabkan oleh pelanggan sendiri, maka akan dikenakan biaya tambahan. Selain itu, terkait penjelasan dari beberapa pelanggan yang melakukan pengaduan terkait biaya pelayananya tidak dipungut biaya/gratis, Namun, penjelasan yang serupa dari beberapa pelanggan terkait sambungan baru menyatakan bahwa terdapat biaya dan biaya tersebut sudah tertera berdasarkan pada Peraturan Direksi PDAM Kabupaten Gresik Nomor 5 Tahun 2014. Akan tetapi terdapat pula biaya lain-lainnya yang harus di tanggung oleh pelanggan PDAM Giri Tirta Kabupaten Gresik.

\section{Ukuran Nilai-nilai Sosial dan Budaya}

Indikator ketuga yaitu ukuran nilai-nilai sosial dan budaya ini adalah sikap dan kemampuan pegawai dalam memberikan pelayanan kepada pelanggan yang melakukan pengaduan. Dalam hal mengukur efektivitas pelayanan pengaduan di PDAM Giri Tirta Kabupaten Gresik, maka peneliti menggunakan beberapa indikator dari Sondang P. Siagian (2019:153). Berikut merupakan hasil wawancara dengan Kepala/sub Bagian Pelayanan Kepelangganan PDAM Giri Tirta Kabupaten Gresik, menyatakan bahwa:

"Sebagai pelayanan publik gitu mbak ya, tentunya sikap ramah itu harus ada sebagai pegawai kepada pelanggan. Untuk mutu atau kualitas kita ada pegangan mbak ya sesuai dengan SOP nya, jadi kita bekerja sesuai dengan SOP yang ada, jadi pengaduan itu harus dimasukkan sistem dulu setelah masuk ke sistem langsung kita berikan SPK, lalu kita masukkan ke berita acara seperti itu. Untuk mutu dan kualitas pelayanannya sudah baik mbak. Ga mungkin dan ga seharusnya bersikap diskriminasi mbak karena itu tentunya tidak diperbolehkan" (Wawancara 22 Januari 2021).

Pendapat lain diungkapkan oleh pegawai Pelayanan Kepelangganan PDAM Giri Tirta Kabupaten Gresik yang dapat melengkapi penjelasan diatas. Hasil wawancara sebagai berikut: 
"Baik, karena memang dituntut untuk bersikap baik, ramah, tanggap kepada pelanggan. Yaa.. prinsip-prinsip pelayanan lah. Di tuntut seperti itu. Mutu dan kualitas pelayanan kalau menurut saya sudah baik mbak. Kalo sampai bersikap diskriminasi ndak ada, gaboleh, dilarang" (Wawancara 25 Januari 2021).

Pendapat lain disampaikan oleh Ahmad Dumairi, yaitu salah satu pelanggan PDAM Giri Tirta Kabupaten Gresik yang melakukan pengaduan di Kantor PDAM Giri Tirta Kabupaten Gresik. Hal ini didukung dengan hasil wawancara sebagai berikut:

"Alhamduillah sikap pegawainya tadi sudah baik, sopan, ramah. Tidak melakukan diskriminasi kok mbak, untuk sikapnya aman" (Wawancara 22 Januari 2021).

Pendapat serupa disampaikan oleh Ibu Ita, yaitu salah satu pelanggan PDAM Giri Tirta Kabupaten Gresik yang telah melakukan pengaduan di Kantor PDAM Giri Tirta Kabupaten Gresik. Hal ini didukung dengan hasil wawancara sebagai berikut:

"Sejauh ini sikap pegawai PDAM kepada saya tadi sangat ramah ya mbak. Gak mbak, gak sampek melakukan diskriminasi mbak" (Wawancara 26 Januari 2021).

Pendapat serupa disampaikan oleh Ibu Komalasari, yaitu salah satu pelanggan PDAM Giri Tirta Kabupaten Gresik yang telah melakukan pembayaran pengaduan di Kantor PDAM Giri Tirta Kabupaten Gresik. Hal ini didukung dengan hasil wawancara sebagai berikut:

"Kurang baik mbak, masa saya bayar tagihan air dan saya minta print sebagai bukti aja mbak-mbak kasirnya judes kalo jawab sama gabisa senyum juga mbak. Tapi ndak sampe melakukan diskriminasi" (Wawancara 26 Januari 2021).

Pendapat serupa disampaikan oleh Ibu Dina, yaitu salah satu pelanggan PDAM Giri Tirta Kabupaten Gresik yang telah melakukan pengaduan di Kantor PDAM Giri Tirta Kabupaten Gresik. Hal ini didukung dengan hasil wawancara sebagai berikut:

"Selama ini untuk sikapnya sendiri sudah bagus, orangnya welcome, enak maksud e kalo kita tanya masalah pasang baru orangnya nerangkan dengan santai ini waktu pegawai bagian lapangan mbak, waktu bapaknya ke rumah saya itu. Ndak, ndak ada diskriminasi” (Wawancara 30 Januari 2021).

Berdasarkan observasi dan wawancara diatas, sikap pegawai dalam memberikan pelayanan kepada pelanggan dengan baik, ramah, dan sopan. Selain itu, tanggap dalam merespon pelanggan. Serta tidak melakukan sikap diskriminasi terhadap pelanggan karena hal tersebut tidak seharusnya dilakukan dalam pelayanan publik.

\section{Ukuran Ketelitian}

Indikator dalam dimensi ini adalah pegawai pelayanan kepelangganan melakukan pelayanan dengan cermat, tepat, dan teliti serta optimal dalam memberikan pelayanan kepada semua pelanggan yang melakukan pengaduan 
baik pengaduan masyarakat mengenai air keruh, air macet, meteran rusak, kebocoran pipa, dan lain sebagainya. Berikut merupakan hasil wawancara dengan Kepala/sub Bagian Pelayanan Kepelangganan PDAM Giri Tirta Kabupaten Gresik, menyatakan bahwa:

"Ya itu mbak sesuai dengan SOP nya aja karena PDAM kan merupakan instansi pelayanan publik, maka sudah seharusnya cermat dan teliti itu tadi dalam bentuk pelayanan apapun itu mbak. Seperti, pemberian informasi, pengaduan, pembayaran, dan customer services. Pelayanan PDAM sudah terbilang optimal cuma kita biasa e itu mbak kekurangan tenaga kerjanya seperti itu makanya kita kan gabisa langsung, maksimal besoknya sudah harus selesai. Seperti itu, jadi kita kekurangannya ya cuma kekurangan tenaga aja. Pelayanan lama itu ini ya mbak karena air tidak keluar dikarenakan adanya kebcoran pipa secara mendadak." (Wawancara 22 Januari 2021).

Pendapat serupa diungkapkan oleh pegawai Pelayanan Kepelangganan PDAM Giri Tirta Kabupaten Gresik yang dapat melengkapi penjelasan diatas. Hasil wawancara sebagai berikut:

"Baik, karena setiap cabang ada customer services, ada penerima pengaduan bagian admin nya. Kan ada trining nya juga 3 bulan sekali ada evaluasi dan lain sebagainya itu. Pelayanannya sudah optimal. Untuk pelayanan yang biasanya lama ini air tidak keluar karena ada mendadak kebocoran pipa dan lain sebagainya" (Wawancara 25 Januari 2021).

Pendapat lain disampaikan oleh Ahmad Dumairi, yaitu salah satu pelanggan PDAM Giri Tirta Kabupaten Gresik yang melakukan pengaduan di Kantor PDAM Giri Tirta Kabupaten Gresik. Hal ini didukung dengan hasil wawancara sebagai berikut:

"Menurut saya sudah teliti mbak, waktu saya tanya pegawainya menjelaskan secara detail, penjelasannya mudah dipahami dan saya paham mengenai penjelasan dari bapaknya tadi mbak. Eee....optimal mbak ya ? saya rasa cukup optimal mbak dengan tadi saya sempet marah karena bapaknya tidak ontime, tapi saat saya di tangani, kemampuan pegawai dalam menangani keluhan saya sudah baik mbak. Jadi saya rasa cukup optimal dalam pelayanannya, gitu mbak" (Wawancara 22 Januari 2021).

Pendapat serupa disampaikan oleh Ibu Ita, yaitu salah satu pelanggan PDAM Giri Tirta Kabupaten Gresik yang telah melakukan pengaduan di Kantor PDAM Giri Tirta Kabupaten Gresik. Hal ini didukung dengan hasil wawancara sebagai berikut:

"Sudah teliti tadi bapaknya mbak, penjelasannya juga udah jelas. Hehe...saya rasa cukup optimal mbak karena tadi saya ditangani juga cukup lama gitu" (Wawancara 26 Januari 2021).

Pendapat serupa disampaikan oleh Ibu Komalasari, yaitu salah satu pelanggan PDAM Giri Tirta Kabupaten Gresik yang telah melakukan pembayaran pengaduan di Kantor PDAM Giri Tirta Kabupaten Gresik. Hal ini didukung dengan hasil wawancara sebagai berikut: 
"Kalo teliti, cermat iya, tapi kalo optimal dalam pelayanannya sih menurut saya kurang mbak, karena mbak kasirnya judes" (Wawancara 26 Januari 2021).

Pendapat serupa disampaikan oleh Ibu Dina, yaitu salah satu pelanggan PDAM Giri Tirta Kabupaten Gresik yang telah melakukan pengaduan di Kantor PDAM Giri Tirta Kabupaten Gresik. Hal ini didukung dengan hasil wawancara sebagai berikut:

"Teliti mbak. Tapi kurang optimal pelayanannya, kaya saya tadi di imbalimbalin kaya gitu, jengkel saya mbak marah saya disitu, lah gimana wong ndak di tangani dengan baik kok" (Wawancara 30 Januari 2021).

Berdasarkan observasi dan wawancara diatas, kecermatan dan ketelitian pegawai dalam memberikan pelayanan kepada pelanggan sudah baik. Selain itu, optimalisasi kinerja pegawai dalam melayani masyarakat yang melakukan pengaduan masih terbilang cukup baik dikarenakan masih ada beberapa alasan dari masyarakat yang melakukan pengaduan.

\section{B. Pembahasan}

\section{Ukuran Waktu dalam Pelayanan Pengaduan PDAM Giri Tirta Kabupaten Gresik.}

Berdasarkan hasil penelitian diketahui bahwa petugas pelayanan pengaduan PDAM Giri Tirta Kabupaten Gresik terkait masalah yang dikeluhkan pelanggan sudah terlaksana dengan baik dan tepat waktu yaitu tidak lebih dari 15 menit sesuai dengan SOP pelayanan pengaduan. Hal diatas menyatakan bahwa sudah sesuai dengan keputusan MENPAN Nomor 63 Tahun 2003, tentang pedoman umum penyelenggaraan pelayanan publik dalam prinsip pelayanan penyelenggaraan publik mendefinisikan bahwa kepastian waktu sebagai pelaksanaan pelayanan publik dapat diselesaikan dalam kurun waktu yang telah ditentukan dan juga sesuai dengan teori dari Sondang P Siagian (2019:153) menyatakan bahwa efektivitas kerja berarti penyelesaian pekerjaan tepat pada waktu yang ditetapkan. Namun, dari hasil wawancara dengan beberapa pelanggan yang telah melakukan pelayanan baik pelayanan pengaduan maupun pelayanan pembayaran tagihan air yaitu pelayanan yang dilakukan belum sesuai dengan waktu pelayanan yang ditentukan oleh pegawai yang seharusnya juga sesuai dengan SOP pelayanan pengaduan di PDAM Giri Tirta Kabupaten Gresik. Maka dalam hal ini penulis menyimpulkan bahwa waktu dalam memberikan pelayanan kepada masyarakat yang melakukan pengaduan belum sesuai dengan standar waktu yang ditentukan.

Berdasarkan uraian pembahasan diatas dapat disimpulkan bahwa pada indikator ukuran waktu pegawai pelayanan kepelangganan PDAM Giri Tirta Kabupaten Gresik perlu memperhatikan lagi agar dapat memenuhi dan meningkatkan kepuasan pelanggan yang sedang melakukan pengaduan atau permintaan 


\section{Ukuran Harga dalam Pelayanan Pengaduan di PDAM Giri Tirta Kabupaten Gresik.}

Harga merupakan rincian biaya yang harus dikeluarkan oleh pelanggan untuk melakukan permintaan kepada pelayanan pengaduan PDAM Giri Tirta Kabupaten Gresik. Berdasarkan hasil penelitian berupa wawancara dengan pegawai pelayanan pengaduan di PDAM Giri Tirta Kabupaten Gresik bahwa pelayanan pengaduan tidak terdapat pemungutan biaya terkait dengan pelayanannya. Namun, apabila sebelum meter terdapat kerusakan meter, maka hal tersebut sudah menjadi tanggungjawab PDAM. Akan tetapi, apabila setelah meter terdapat kerusakan meter atau hilangnya meter yang disebabkan oleh pelanggan sendiri, maka akan dikenakan biaya tambahan sebesar Rp.250.000. Selain itu terdapat uraian penjelasan dari beberapa pelanggan yang melakukan pengaduan terkait biaya pelayananya menyatakan bahwa pelayanan tidak dipungut biaya/gratis dan dari penjelasan pelanggan yang sedang melakukan sambungan baru menyatakan bahwa terdapat biaya, besaran biaya yang dikeluarkan pelanggan untuk pemasangan baru yaitu sekitar 2.000.000 dan biaya tersebut sudah tertera berdasarkan pada Peraturan Direksi PDAM Kabupaten Gresik Nomor 5 Tahun 2014. Hal tersebut sesuai dengan pendapat dari Hardiansyah (2018:39-40) yang menyatakan bahwa maklumat pelayanan merupakan bentuk legalitas yang memberikan hak kepada masyarakat untuk mendapatkan akses pelayanan publik yang sesuai dengan harapan dan kebutuhannya, perlindungan atau pengayoman, kepastian biaya yang mengajukan keluhan dan pengaduan yang melakukan pengawasan.

Berdasarkan uraian pembahasan diatas dapat disimpulkan bahwa pada indikator ukuran harga, pelayanan pengaduan di PDAM Giri Tirta Kabupaten Gresik sudah baik karena sudah sesuai dengan Peraturan Direksi PDAM Kabupaten Gresik Nomor 5 Tahun 2014.

\section{Ukuran Nilai-nilai Sosial dan Budaya dalam Pelayanan Pengaduan di} PDAM Giri Tirta Kabupaten Gresik.

Ukuran nilai-nilai sosial dan budaya merupakan sikap dan kemampuan pegawai pelayanan publik dalam memberikan pelayanan yang sebaik mungkin kepada pelanggannya. Hal ini ukuran nilai-nilai sosial dan budaya melihat sejauh mana sikap pegawai kepelangganan dalam memberikan pelayanan kepada pelanggan yang melakukan keluhan atau pengaduan. Berdasarkan hasil penelitian berupa wawancara dengan pegawai pelayanan pengaduan di PDAM Giri Tirta Kabupaten Gresik bahwa pegawai pelayanan pengaduan sudah memberikan sikap yang baik kepada pelanggan yang melakukan pengaduan. Sikap yang baik ini, seperti sopan santun dan ramah kepada pelanggan yang melakukan pengaduan. Serta tidak melakukan sikap diskriminasi terhadap pelanggan karena hal itu sudah menjadi ketidak bolehan dalam memberikan pelayanan publik. Selain itu, pendapat yang serupa dari pelanggan yang melakukan pengaduan bahwa sikap pegawai dalam memberikan pelayanan 
kepada pelanggan dengan baik, ramah, dan sopan. Serta tidak melakukan sikap diskriminasi terhadap pelanggan. Hal tersebut sesuai dengan pendapat Tjiptono dikutip oleh Hardiansyah (2018:73) menyatakan bahwa salah satunya yaitu kemudahan dalam melakukan hubungan komunikasi yang baik, perhatian pribadi, dan memahami kebutuhan pada pelanggan.

Berdasarkan uraian diatas dapat disimpulkan bahwa pada indikator ukuran nilai-nilai sosial dan budaya dapat dikatakan bahwa petugas PDAM Giri Tirta Kabupaten Gresik telah memberikan pelayanan pengaduan yang baik dan dapat dibuktikan dalam melakukan hubungan komunikasi yang baik, perhatian pribadi, memahami kebutuhan pelanggan dalam melakukan pelayanan pengaduan dengan sebaik mungkin sehingga dapat menciptakan kepuasan pelanggan terhadap pelayanan yang diberikan.

\section{Ukuran Ketelitian}

Dalam surat keputusan Menpan No 63 Tahun 2003 tentang pedoman umum penyelenggaraan pelayanan publik mendefinisikan tanggungjawab sebagai pemimpin penyelenggaraan pelayanan publik atau pejabat yang ditunjuk bertanggungjawab atas penyelenggaraan pelayanan dan penyelesaian keluhan atau persoalan dalam pelaksanaan pelayanan publik. Ukuran ketelitian ini dimaksudkan ketelitian dan ke optimalan pegawai pelayanan pengaduan dalam memberikan pelayanan kepada semua pelanggan yang melakukan pengaduan. Berdasarkan hasil penelitian berupa wawancara kepada beberapa pegawai pelayanan pengaduan PDAM Giri Tirta Kabupaten Gresik menunjukkan petugas sudah teliti atau akurat dalam memberikan jasa pelayanan kepada pelanggan yang melakukan pengaduan. Hal tersebut sesuai dengan teori dari Sondang P Siagian (2019:153) menyatakan bahwa efektivitas pelayanan diukur dari salah satu indikator ukuran ketelitian yaitu menunjukkan jasa yang diberikan akurat atau tidak. Namun harus diperhatikan mengenai optimalisasi kinerja pegawai dalam melayani masyarakat yang melakukan pengaduan masih terbilang cukup baik dan lebih di tingkatkan lagi dikarenakan masih adanya keluhan mengenai mutu kualitas pelayanan pengaduan.

\section{Kesimpulan}

Kesimpulan dari penelitian ini, sebagai berikut : Ukuran waktu dalam pelayanan ini terbilang kurang efektif dan kurang maksimal. Petugas menyelesaikan pelayanan kepada pelanggan belum sesuai dengan ukuran waktu yang telah dilakukan. Serta penanganan dari pengaduan pelanggan dilakukan belum sesuai dengan standar waktu yang telah ditetapkan oleh PDAM Giri Tirta Kabupaten Gresik.

Harga yang dikeluarkan oleh pelanggan untuk mendapatkan pelayanan pengaduan sudah efektif karena sesuai dengan biaya operasional yang telah ditentukan oleh PDAM Giri Tirta Kabupaten Gresik. Namun, biaya yang dibutuhkan dalam pemasangan baru sebesar Rp.2000.000,-. Dalam perbaikan mengenai air macet tidak ada pungutan 
perbaikan, apabila meteran rusak dan meteran hilang setelah meter terdapat biaya tambahan sebesar Rp. 250.000,-.

Ukuran Nilai-nilai Sosial dan Budaya menunjukan sikap pegawai dalam pelayanan ini terbilang baik dengan memberikan pelayanan yang ramah, sopan, serta tanggap dalam merespon pelanggan. Selain itu tidak melakukan sikap diskriminasi terhadap pelanggan yang melakukan pengaduan.

Adapun ukuran ketelitian Ukuran ketelitian dalam pelayanan ini cukup efektif. Pegawai memberikan jasa pelayanan kepada pelanggan yang melakukan pengaduan dengan akurat atau teliti. Namun, Namun dapat diperhatikan mengenai optimalisasi kinerja pegawai dalam melayani masyarakat yang melakukan pengaduan masih terbilang cukup baik dan lebih di tingkatkan lagi dikarenakan masih adanya keluhan mengenai mutu kualitas pelayanan pengaduan. 


\section{BIBLIOGRAFI}

Ardianor, \& Suriyani, Eddy. (2017). Efektivitas Pelayanan Pembuatan Kartu Tanda Penduduk Elektronik (KTP-EL) Di Kantor Kecamatan Bintang Ara Kabupaten Tabalong. Jurnal Pemikiran Dan Penelitian Administrasi Publik Dan Administrasi Bisnis, 1(2), 463-473.

Febliany, Imelda, Fitriyah, Nur, \& Paselle, Enos. (2017). Efektivitas Pelayanan Terpadu Satu Pintu Terhadap Penyerapan Investasi Di Kalimantan Timur (Studi pada Badan Perijinan dan Penanaman Modal Daerah Provinsi Kalimantan Timur). Jurnal Administrative Reform (JAR), 2(3), 410-420.

Hardiansyah. (2018). Kualitas Pelayanan Publik Konsep Dimensi Indikator dan Implementasinya. In Gava Media. Retrieved from http://repository.usu.ac.id/bitstream/123456789/23790/4/Chapter I.pdf

Indrawati, Weni, Suntoro, Irawan, \& Nurmalisa, Yunisca. (2017). Efektivitas Kinerja Aparatur Desa Dalam Pelayanan Publik Kepada Masyarakat Di Desa Tanggulangin. Jurnal Kultur Demokrasi, 5(4).

J Jumarianto. (2017). Efektivitas Pelayanan Publik Berdasarkan Undang-Undang Nomor 24 Tahun 2013 (Studi Penelitian pada Kantor Kecamatan Barambai Kabupaten Barito Kuala). Jurnal Teknologi, 1(1).

Kemenpan. (2017). Peraturan Menteri Pendayagunaan Aparatur Negara Dan Reformasi Birokrasi Republik Indonesia Nomor 14 Tahun 2017 Tentang Pedoman Penyusunan Survei Kepuasan Masyarakat Unit Penyelenggara Pelayanan Publik. Pedoman Penyusunan Survei Kepuasan Masyarakat Unit Penyelenggara Pelayanan Publik, (708), 1-30.

Oktasari, Defi Maya. (2015). Implementasi Kepmen Pan No. 63 Tahun 2003 Tentang Pedoman Umum Penyelenggaraan Publik Di Kantor Kecamatan Sepaku Kabupaten Penajam Paser Utara. Jurnal Pemerintahan, 3(2), 2257-2262.

PDAM Giri Tirta Kabupaten Gresik. (n.d.). Retrieved from http://pdam.gresikkab.go.id/

Ruru, Ambron Sius Mamo Patar Rumapea Joorie. (2015). Pengaruh Iklim Organisasi Terhadap Efektifitas Pelayanan Publik Di Kecamatan Taliabu Utara Kabupaten Kepulauan Sula. Jurnal Administrasi Publik (JAP), 4(32).

Sari, Nur Habiba Febriantika dan Slamet Muchsin dan Sunariyanto. (2019). Efektivitas Pelayanan Kesehatan Pasien Bpjs (Badan Penyelenggara Jaminan Sosial) Di Puskesmas (Studi Kasus Di Puskesmas Dinoyo Kota Malang). Respon Publik, 13(3), 113-121.

Siagian, Sondang P. (2019). Organisasi Kepemimpinan \& Perilaku Administrasi (9th ed.). Jakarta: PT. Gunung Agung. 
Lulu Syafirah dan Ertien Rining Nawangsari

Sugiyono. (2019). Metode Penelitian Kuantitatif, Kualitatif, Dan R\&D (27th ed.). Bandung.

Undang-Undang Nomor 25 Tahun 2009 Tentang Pelayanan Publik. , (2009).

Undang-Undang Republik Indonesia Nomor 7 Tahun 2004 Tentang Sumber Daya Air. , (2004).

Undang-Undang RI No.5. (1962). Undang-Undang Republik Indonesia Nomor 5 Tahun 1962 tentang Perusahaan Daerah. 1959(60), 1-22.

Waruwu, Henrikus, \& Masitho, Beby. (2016). Efektivitas Pelayanan Paspor Pada Kantor Imigrasi Kelas I Khusus Medan. Jurnal Administrasi Publik, 4(1), 43-51. Retrieved from http://ojs.uma.ac.id/index.php/publikauma\%0AEfektivitas 